\title{
Cotton aphid feeding preference and the development of watermelon plants treated with silicon
}

\author{
Preferência alimentar do pulgão-do-algodoeiro e desenvolvimento de plantas de melancia tratadas \\ com silício
}

\author{
Rosane Rodrigues da Costa Pereira', Mara Pestana Leite ${ }^{2}$, Douglas Marcelo Pinheiro da Silva ${ }^{2}$, \\ Ronelza Rodrigues da Costa Zaché ${ }^{3}$, Carlos Eduardo Pereira ${ }^{*}$ \\ ${ }^{1}$ Federal University of Southern Bahia, Itabuna, BA, Brazil. * Author for correspondence: cepereira.ufsb@gmail.com
${ }^{2}$ Federal University of Amazonas, Humaitá, AM, Brazil. \\ ${ }^{3}$ Federal Rural University of Amazon, Parauapebas, PA, Brazil.
}

Submission: 30/03/2021 / Acceptance: 08/06/2021

\begin{abstract}
The cotton aphid is one of the main watermelon crop pests and may cause a reduction in productivity due to the suction of sap, the transmission of viruses, and decreased photosynthetic capacity. The objective of this research was to evaluate the feeding preference of the aphid Aphis gossypii and the biometric aspects of watermelon cultivar plants submitted to silicon application. The experiment was conducted at the Institute of Education, Agriculture, and Environment of the Federal University of Amazonas, in Humaitá, Brazil. A randomized complete block design was used for testing preference with choice and a completely randomized design to study the biometric parameters of the plants. The treatments were distributed in a 2 x 3 factorial scheme (with and without silicon and considering cultivars Crimson Sweet, Fairfax, and Charleston). Silicic acid was applied at a $1 \%$ concentration directly on the substrate around the plants (equivalent to $1 \mathrm{t} \mathrm{SiO}_{2} \mathrm{ha}^{-1}$ ), 25 days after sowing. The aphids in the breeding were kept in cucumber plants of cultivar Caipira. The treatments were evaluated through the preference test on watermelon cultivars and biometric studies of plant growth and development. The data were submitted to an analysis of variance, and the means were compared using the $\mathrm{F}$ and Scott-Knott tests at the $5 \%$ probability level. Silicon does not affect the preference of Aphis gossypii in different watermelon cultivars and negatively affects plant growth and development.
\end{abstract}

KEYWORDS: silicic acid; Aphis gossypii; Citrullus lanatus.

\section{RESUMO}

O pulgão-do-algodoeiro é uma das principais pragas da cultura da melancia e pode provocar redução na produtividade devido à sucção de seiva; transmissão de vírus e diminuição da capacidade fotossintética. Nesse sentido, o objetivo, nesta pesquisa, foi avaliar a preferência do pulgão Aphis gossypii e os aspectos biométricos de plantas de cultivares de melancia submetidas à aplicação de silício. $\mathrm{O}$ experimento foi conduzido no Instituto de Educação, Agricultura e Ambiente da Universidade Federal do Amazonas, Humaitá, Brasil. Utilizou-se o delineamento experimental em blocos completos casualizados para teste de preferência com chance de escolha e o inteiramente ao acaso para o estudo dos parâmetros biométricos das plantas, onde os tratamentos foram distribuídos em esquema fatorial 2 (sem silício e com silício) $\times 3$ (cultivares: Crimson Sweet, Fairfax e Charleston). O ácido silícico foi aplicado a $1 \%$ diretamente no substrato ao redor das plantas (equivalente a $1 \mathrm{t} \mathrm{SiO}_{2}$ ha $^{-1}$ ), 25 dias após a semeadura. Os pulgões da criação foram mantidos em plantas de pepino, cultivar Caipira. Os tratamentos foram avaliados por meio do teste de preferência em cultivares de melancia e de estudos biométricos de crescimento e desenvolvimento das plantas. Os dados foram submetidos à análise de variância e as médias comparadas pelo teste de $\mathrm{F}$ e Scott \& Knott ao nível de $5 \%$ de probabilidade. O silício não afeta a preferência de Aphis gossypii em diferentes cultivares de melancia e afeta negativamente o crescimento e desenvolvimento das plantas.

PALAVRAS-CHAVE: ácido silício; Aphis gossypii; Citrullus lanatus. 


\section{INTRODUCTION}

There are over 100 thousand hectares planted with watermelon, Citrullus lanatus (Thunb.) Matsum \& Nakai, in Brazil, with a production of approximately 2.2 million tons in 2018 (IBGE, 2018). This Cucurbitaceae is a source of income and employment (OLIVEIRA et al., 2012) and is important to family farmers in the state of Amazonas.

The aphid Aphis gossypii Glover (Hemiptera: Aphididae) is one of the main watermelon crop pests. It suctions plant sap, causing deformity in leaves and branches and reducing the photosynthetic capacity of plants, and may transmit some viruses (PINTO et al., 2008). Chemical control is the most used method, but studies on new control tactics are necessary to reduce the use of pesticides in Integrated Pest Management (IPM) and their impacts on the environment, the health of the applicator, and pest resistance, as well as decrease insecticide residues in fruits.

Therefore, the study of constitutive resistance, characterized by the intrinsic defense mechanisms of plants that hamper herbivory, and induced resistance, which occurs through morphological or physiological changes resulting from the action of herbivores on the plant (FREITAS et al., 2018), may contribute to reducing agrochemical use. Regarding watermelon crops, these studies may contribute to reducing the application of pesticides. Resistance is an efficient and promising method in the management of arthropods showing stability, low risk of causing environmental imbalance, easy use, financial viability, reduction in production costs, and compatibility with other control methods (BOIÇA JÚNIOR et al., 2013). In research with cotton (Gossypium hirsutum), resistant genotypes negatively affected the biological aspects of the aphid $A$. gossypii (ALCANTRA et al., 2019).

Induced resistance (IR) is defined as the increase in the defensive capacity of plants against pests, being acquired after an appropriate stimulus and involving the activation of latent resistance mechanisms in plants. This plant resistance to insect pests may be induced by chemicals called elicitors (WAR et al., 2012). Silicon $(\mathrm{Si})$ is an element that may confer resistance to insects by physical and biochemical or molecular factors (REYNOLDS et al., 2016), and may be accumulated in epidermis cells, making them rigid and difficult for insects to feed on (YANG et al., 2018). Si may also promote in plants the synthesis of defense compounds against the action of phytophagous pests (KVEDARAS et al., 2010).

Plants are classified as accumulators, intermediates, and non-accumulators of $\mathrm{Si}$ depending on the $\mathrm{Si} / \mathrm{Ca}$ ratio in the tissues. Ratios above 1 indicate accumulating plants, while plants with ratios between 1 and 0.5 are intermediates, and with ratios under 0.5 are non-accumulating (MA \& YAMAJI, 2015). Cucurbits such as watermelon and melon are considered intermediates.

In Agriculture, although $\mathrm{Si}$ is not considered an essential element, it is reported in the literature as responsible for improving the productivity of several crops (GUNTZER et al., 2012; CHAGAS et al., 2016; PRESTON et al., 2021) and an elicitor of resistance in plants. Soil fertilization by natural silicates has the potential to mitigate environmental stresses and nutrient depletion by its ability to regulate the absorption of soil nutrients in different crops and, consequently, reduce the extensive use of fertilizers (GUNTZER et al., 2012). Application of Si improves the yield and quality of rice and millet (CHAGAS et al., 2016) and increases the accumulation of biomass and nutrients in melon plants (PRESTON et al., 2021).

Thus, this research aimed to evaluate the feeding preference of the aphid Aphis gossypii and the biometric aspects of watermelon cultivar plants submitted to silicon application.

\section{MATERIAL AND METHODS}

The experiment was conducted in a greenhouse and an air-conditioned room at the Plant Health Laboratory of the Institute of Education, Agriculture, and Environment (IEAA) of the Federal University of Amazonas (UFAM), in the municipality of Humaitá, in the south of the state of Amazonas, Brazil. We used the randomized blocks experimental design for the multiple-choice feeding preference test and the completely randomized design for studying the biometric parameters of the watermelon plants. The treatments were distributed in a $2 \times 3$ factorial scheme (with and without silicon, and considering cultivars Crimson Sweet, Charleston, and Fairfax).

Four watermelon seeds were sown in each pot with $10 \mathrm{~kg}$ of a substrate composed of soil and tanned bovine manure at a 3:1 ratio. The pots were placed in the greenhouse. After twenty days of sowing, thinning was carried out, leaving one plant per pot. The silicic acid was diluted in water and applied twenty-five days after sowing at a $1 \%$ concentration directly on the substrate around the plants, with a dose equivalent to $1 \mathrm{t}$ $\mathrm{SiO}_{2} \mathrm{ha}^{-1}$.

The aphids were collected from commercial watermelon crops with the Top Gun cultivar in the municipality of Humaitá, Amazonas, Brazil. The insects were kept in an air-conditioned room in the laboratory, at $25 \pm 2 \stackrel{\circ}{ } \mathrm{C}$ and $12 \mathrm{~h}$ of photophase. To provide food for the breeding of $A$. gossypii, cucumber 
plants (Cucumis sativus) of cultivar Caipira were grown in a greenhouse using pots with $5 \mathrm{~kg}$ of substrate. The insects were kept in cucumber leaves of $8 \mathrm{~cm}$ in diameter, which were washed in water and placed in a $1 \%$ hypochlorite solution for $5 \mathrm{~min}$. Then, the leaves were placed in Petri dishes with a layer of $1 \%$ Agarwater to maintain leaf turgor. The Petri dishes were closed with a thin tissue (voi) using rubber ties. When the leaves turned yellow, they were replaced.

For the multiple-choice feeding preference test ten and twenty days after the application of silicon, we used the youngest fully expanded leaves measuring from $8 \mathrm{~cm}$ to $10 \mathrm{~cm}$ in length for each repetition. In the laboratory, the leaves were washed with water and, subsequently, immersed in a $1 \%$ sodium hypochlorite solution for $3 \mathrm{~min}$.

After removing the excess surface water, the leaves were cut into sections $6 \mathrm{~cm}$ long and $2 \mathrm{~cm}$ wide and fixed in Petri dishes of $20 \mathrm{~cm}$ in diameter containing 1\% Agar gel and covered with perforated PVC film. The identification of treatments and repetitions was performed on the Petri dishes with a permanent marker. Each Petri dish corresponded to a block with all treatments, and ten repetitions were used. Subsequently, 24 adult aphids kept without food for $1 \mathrm{~h}$ before the start of the test were released at the center of each plate. The Petri dishes were kept in an air-conditioned room at the IEAA Plant Health Laboratory at $25 \pm 2{ }^{\circ} \mathrm{C}$ and $12 \mathrm{~h}$ photophase until the end of the test, following a methodology adapted from COSTA \& MORAES (2006). The evaluation was carried out $72 \mathrm{~h}$ after the aphids were released on the Petri dishes by counting the number of adults and nymphs present in each leaf section, according to CRUZ et al. (1998).

For studying the biometric parameters of the watermelon plants, the plants were transferred ten days after the silicon application to individualized cages surrounded by voil tissue and arranged randomly in the greenhouse of the IEAA/UFAM. The plants were infested with 50 adult aphids per plant. The aphids were kept on the plants for ten days and later removed. The parameters evaluated were the number of leaves per plant ten and thirty days after infestation and the root and aerial dry mass thirty days after infestation. Each pot with a plant represented an experimental plot, using six replications.

The data were subjected to an analysis of variance using the computational package SISVAR, version 4.0 (FERREIRA, 2014). The averages were compared by the $\mathrm{F}$ and Scott-Knott tests at the $5 \%$ probability level. The data on the number of insects and leaves were transformed to $\sqrt{ }(X+0.5)$.

\section{RESULTS AND DISCUSSION}

There was no statistically significant difference in feeding preference of adult Aphis gossypii individuals ten days $(1.93 \pm 0.21)$ and twenty days $(3.20 \pm 0.43)$ after the silicon application, nor of nymphs (15.45 \pm 1.53 and $18.13 \pm 1.67$, respectively), considering three watermelon cultivars $72 \mathrm{~h}$ after aphid release (Table 1).

Table 1. Analysis of variance for data on the number of nymphs $(\mathrm{N})$ and adults $(\mathrm{A})$ of Aphis gossypii in the feeding preference test ten and twenty days after the silicon application on different watermelon cultivars.

\begin{tabular}{llllll}
\hline SV & DF & \multicolumn{4}{c}{ Mean Squares } \\
\cline { 3 - 5 } & & $\mathrm{N} 10$ & $\mathrm{~A} 10$ & $\mathrm{~N} 20$ & $\mathrm{~A} 20$ \\
\hline Silicon & 1 & $0.919^{\mathrm{ns}}$ & $0.631^{\mathrm{ns}}$ & $0.010^{\text {ns }}$ & $0.023^{\text {ns }}$ \\
Cultivar & 2 & $2.950^{\text {ns }}$ & $0.976^{\text {ns }}$ & $1.254^{\text {ns }}$ & $0.054^{\text {ns }}$ \\
Silicon x Cultivar & 2 & $1.145^{\text {ns }}$ & $0.420^{\text {ns }}$ & $3.934^{\text {ns }}$ & $0.321^{\text {ns }}$ \\
Residual & 54 & 2.495 & 0.409 & 3.051 & 0.760 \\
\hline ns & 54 &
\end{tabular}

${ }^{n s}$ Not significant; SV: source of variation; DF: degrees of freedom. Data were transformed to $\sqrt{ }(X+0.5)$.

In this study, no differences were observed in the preference of aphids for Crimson Sweet, Charleston, and Fairfax watermelon cultivars. However, MARSARO JÚNIOR et al. (2009) analyzed the resistance of 29 watermelon accessions of the aphid $A$. gossypii and verified the occurrence of different degrees of resistance. Thus, it is important to continue studies on the resistance of watermelon cultivars to this aphid, as this control method may reduce the exclusive use of chemical control adopted in watermelon-producing regions and, consequently, cause less environmental impact because most phytosanitary products registered for $A$. gossypii in watermelon are classified as hazardous to the environment (AGROFIT, 2021).

The silicon application did not affect the choice by $A$. gossypii in any evaluation period. There were likely not enough chemical, physical, and morphological stimuli by silicon to cause a difference in the host plant selection by the insect. The induction of plant resistance to pest insects may be influenced by some factors such as environmental conditions, the genotype studied, and plant nutrition (WALTERS et al., 2013). 
COSTA \& MORAES (2006) also observed no effect of silicon on the preference of the green aphid Schizaphis graminum in wheat plants. However, GOMES et al. (2008) observed that Myzus persicae did not prefer potato plants treated with silicon. CARVALHO et al. (1999), while working with sorghum in a multiplechoice test, found that $63 \mathrm{~h}$ after the release of the aphids $S$. graminum, the untreated plants had twice as many aphids compared to those treated with silicon. PORTELA et al. (2019) tested the induction of the bean plant resistance to the black aphid Aphis craccivora Koch and found that the application of silicon negatively affected insect fertility.

There was a statistically significant difference in the number of leaves of watermelon cultivars submitted to the application of silicon only when evaluated ten days after infestation with $A$. gossypii. The same occurred for shoot dry matter, and, for root dry matter, a significant effect was only observed for the cultivars (Table 2).

Table 2. Analysis of variance for data on the number of leaves (NL) ten and thirty days after Aphis gossypii infestation and shoot dry matter (SDM) and root dry matter (RDM) thirty days after infestation in different watermelon cultivars treated or not with silicon.

\begin{tabular}{|c|c|c|c|c|c|}
\hline \multirow[t]{2}{*}{ SV } & \multirow[t]{2}{*}{ DF } & \multicolumn{4}{|c|}{ Mean Squares } \\
\hline & & NL10 & NL30 & SDM & RDM \\
\hline Silicon & 1 & $8.421^{*}$ & $2.051^{\mathrm{ns}}$ & $4.408^{*}$ & $0.0108^{\mathrm{ns}}$ \\
\hline Cultivar & 2 & $2.182^{\mathrm{ns}}$ & $2.712^{\mathrm{ns}}$ & $1.137^{\text {ns }}$ & $0.0233^{* *}$ \\
\hline Silicon $\times$ Cultivar & 2 & $2.864^{\text {ns }}$ & $4.263^{\text {ns }}$ & $1.471^{\mathrm{ns}}$ & $0.0001^{\text {ns }}$ \\
\hline Residual & 24 & 1.705 & 2.144 & 0.995 & 0.0066 \\
\hline
\end{tabular}

The silicon application statistically decreased the number of leaves and the dry matter of the aerial part (Table 3). The watermelon plants are classified as intermediate relative to $\mathrm{Si}$ accumulation, but this element did not affect the preference by $A$. gossypii; it caused a reduction in the dry matter of the aerial part. One of the main limitations of applying high doses of $\mathrm{Si}$ to the soil is the $\mathrm{pH}$ change, which may cause nutritional limitations for plant growth. Thus, CARVALHO FILHO et al. (2007) found that corn plants submitted to fertilization with agrosilicon in doses greater than $0.2 \mathrm{t} \mathrm{ha}^{-1}$ showed symptoms of toxicity such as reduced root growth, increasing $\mathrm{pH}$ and causing fertilizer salinity, affecting the osmotic potential.

CAVALCANTE (2013) found that Brachiaria decumbens plants that received $2.4 \mathrm{t} \mathrm{ha}^{-1}$ of silicate reduced five times the dry matter production of the aerial part and that the soil treated with silicate showed sodium levels almost three times higher than that of the control treatment (without $\mathrm{Si}$ application).

Table 3. Number of leaves ten days after infestation (NL10), shoot dry matter (SDM), and root dry matter (RDM) of watermelon cultivars submitted to silicon application and infestation with Aphis gossypii.

\begin{tabular}{lcc}
\hline SILICON & NL10 & SDM $(\mathrm{g})$ \\
\hline With & $7.93 \pm 1.894 \mathrm{~b}$ & $0.81 \pm 0.078 \mathrm{~b}$ \\
Without & $14.13 \pm 2.180 \mathrm{a}$ & $1.58 \pm 0.364 \mathrm{a}$ \\
\hline CV $(\%)^{*}$ & - & 83.61 \\
\hline CULTIVARS & \multicolumn{3}{c}{ RDM $(\mathrm{g})$} \\
\hline Crimson Sweet & \multicolumn{3}{c}{$0.13 \pm 0.003 \mathrm{~b}$} \\
Fairfax & \multicolumn{3}{c}{$0.20 \pm 0.030 \mathrm{a}$} \\
Charleston & \multicolumn{3}{c}{$0.11 \pm 0.016 \mathrm{~b}$} \\
\hline CV $\%)$ & 55.92 &
\end{tabular}

Means of silicon and cultivar factor, followed by the same letter, did not differ by $F(p \leq 0.05)$ and Scott-Knott $(p<0.05)$ tests, respectively. ${ }^{*} \mathrm{CV}$ : coefficient of variation.

The root dry matter of the watermelon plants of the cultivar Fairfax was higher than those of Crimson Sweet and Charleston plants, regardless of the application of silicon. According to OLIVEIRA et al. (2015), the Fairfax cultivar may present a higher value of dry phytomass of the root system compared to the Crimson Sweet cultivar depending on the environment.

\section{CONCLUSION}

Silicon does not affect the feeding preference by Aphis gossypii in different watermelon cultivars.

The application of silicon, under the conditions of this experiment, negatively affects the growth of watermelon plants. 
Viana et al.

\section{ACKNOWLEDGEMENTS}

The authors would like to thank the FAPEAM for the scholarship and CNPq for the financial support (Process 482220/2011-2).

\section{REFERENCES}

AGROFIT. 2021. Sistemas de agrotóxicos fitossanitários. Available at: https://agrofit.agricultura.gov.br/agrofit_cons/principal_agrofit_cons. Acess on: May 24. 2021.

ALCANTRA E et al. 2019. Resistência induzida ao pulgão-do-algodoeiro em cultivares de algodão colorido. Revista de Ciências Agrárias 42: 483-491.

BOIÇA JÚNIOR AL et al. 2013. Atualidades em resistência de plantas a insetos. In: BUSOLI AC et al. (Ed.). Tópicos em Entomologia Agrícola VI. Jaboticabal: Gráfica e Editora Multipress. p.207-224.

CARVALHO FILHO A et al. 2007. Agressividade da adubação com silicato sobre a germinação do milho. Scientia Agraria 8: 199-203.

CARVALHO SP et al. 1999. Efeito do silício na resistência do sorgo (Sorghum bicolor) ao pulgão-verde Shizaphis graminum (Rond.) (Homoptera: Aphididae). Anais da Sociedade Entomológica do Brasil 28: 505-510.

CAVALCANTE AMLN. 2013. Interferência de doses crescentes de silício na absorção de nutrientes e na matéria seca de Brachiaria decumbens Stapf. Dissertação (Mestrado em Agronomia Tropical). Manaus: UFAM. 43p.

CHAGAS RCS et al. 2016. Silicon fertilization improve yield and quality of rice and pearl millet in cerrado soil. Bioscience Journal 32: 899-907.

COSTA RR \& MORAES JC. 2006. Efeitos do ácido silícico e do acibenzolar-S-methyl sobre Schizaphis graminium (Rondani) (Hemiptera: Aphididae) em plantas de trigo. Neotropical Entomology 5: 834-839.

CRUZ I et al. 1998. Determinação do período de avaliação de não-preferência de sorgo ao pulgão-verde, Schizaphis graminum (Rond.) (Homoptera: Aphididae). Anais da Sociedade Entomológica do Brasil 27: 299-302.

FERREIRA DF. 2014. Sisvar: a guide for its bootstrap procedures in multiple comparisons. Ciência e Agrotecnologia 38 : 109-112.

FREITAS MM et al. 2018. Soybean defense induction to Spodoptera cosmioides herbivory is dependent on plant genotype and leaf position. Arthropod-Plant Interactions 12: 85-96.

GOMES FB et al. 2008. Uso de silício como indutor de resistência em batata a Myzus persicae (Sulzer) (Hemiptera: Aphididae). Neotropical Entomology 37: 185-190.

GUNTZER F et al. 2012. Benefits of plant silicon for crops: a review. Agronomy for Sustainable Development 32: 201213.

IBGE. 2018. Instituto Brasileiro de Geografia e Estatística. SIDRA: bancos de tabelas estatísticas. Disponível em: https://sidra.ibge.gov.br. Acesso em: 30 mar. 2021.

KVEDARAS OL et al. 2010. Silicon enhances natural enemy attraction and biological control through induced plant defences. Bulletion of Entomological Research 100: 367-371.

MA JF \& YAMAJI N. 2015. A cooperative system of silicon transport in plants. Trends in Plant Science 20: 435-442.

MARSARO JÚNIOR AL et al. 2009. Resistência de acessos de melancia ao pulgão Aphis gossypii Glover (Hemiptera: Aphididae) no estado de Roraima, Brasil. Revista Acadêmica: Ciências Agrárias e Ambientais 7: 85-90.

OLIVEIRA AMD et al. 2015. Produção de mudas de melancia em diferentes ambientes e de frutos a campo. Revista Ceres 62: 87-92.

OLIVEIRA PGF et al. 2012. Eficiência de uso dos fatores de produção água e potássio na cultura da melancia irrigada com água de reuso. Revista Brasileira de Engenharia Agrícola e Ambiental 16: 153-158.

PINTO ZV et al. 2008. Ability of Aphis gossypii and Myzus persicae to transmit Cucumber mosaic virus in single and mixed infection with two Potyviruses to zucchini squash. Summa Phytopathologica 34: 183-185.

PORTELA GLF et al. 2019. Silicon as resistance inducer in to control black aphid Aphis craccivora Koch, 1854 in Phaseolus lunatus lima beans. Arquivos do Instituto Biológico 86: e0512018.

PRESTON HAF et al. 2021. Silicon slag increases melon growth and resistance to bacterial fruit blotch. Acta Scientiarum Agronomy 43: e45075.

REYNOLDS OL et al. 2016. Silicon: potential to promote direct and indirect effects on plant defense against arthropod pests in agriculture. Frontiers in Plant Science 7: 1-13.

WALTERS DR et al. 2013. Controlling crop diseases using induced resistance: challenges for the future. Journal of Experimental Botany 64: 1263-1280.

WAR AR et al. 2012. Mechanisms of plant defense against insect herbivores. Plant Signaling \& Behavior 7: 1306-1320.

YANG L et al. 2018. Silicon amendment to rice plants contributes to reduced feeding in a phloem- sucking insect through modulation of callose deposition. Ecology and Evolution 8: 631-637. 